\title{
The doctor in this House: lessons from TV's Gregory House, M.D.
}

$\mathrm{N}$ obody likes Greg House, the title character of Fox's extraordinarily successful television show House, M.D. Played by British actor Hugh Laurie, the Vicodinpopping House insults his colleagues, demeans the medical fellows who work for him, disregards hospital policy, ignores patient wishes and dismisses as irrelevant both basic rules of medical ethics and the law.

And yet, House is respected by colleagues, admired by underlings and trusted by the patients who appear on his service. Every Tuesday night, millions of TV viewers watch as House struggles with a case whose symptomology appears to defy rational explanation and the best tests modern medicine can provide.

"Is there a doctor in this House?" huffs one medical reviewer. ${ }^{1}$ Why love the character whose medicine we would in reality reject? Television is the fMRI of culture studies, the diagnostic by which we see beneath the platitudinous assumptions of social and professional promise to the pulsing realities beneath. Therein lies the show's appeal.

Greg House's single most attractive characteristic is that while eager to be right he is usually wrong, at least until the final minutes of an episode. The secret of House's success lies in his repeated acceptance of diagnostic failures and his unrelenting search for a better understanding of the disease itself. Like Sherlock Holmes, House (whose house number is $22 \mathrm{IB}$, a bow to the master's Baker Street residence) focuses not on personalities but on the core problem. Like Holmes, House's stock in trade is not simply superior

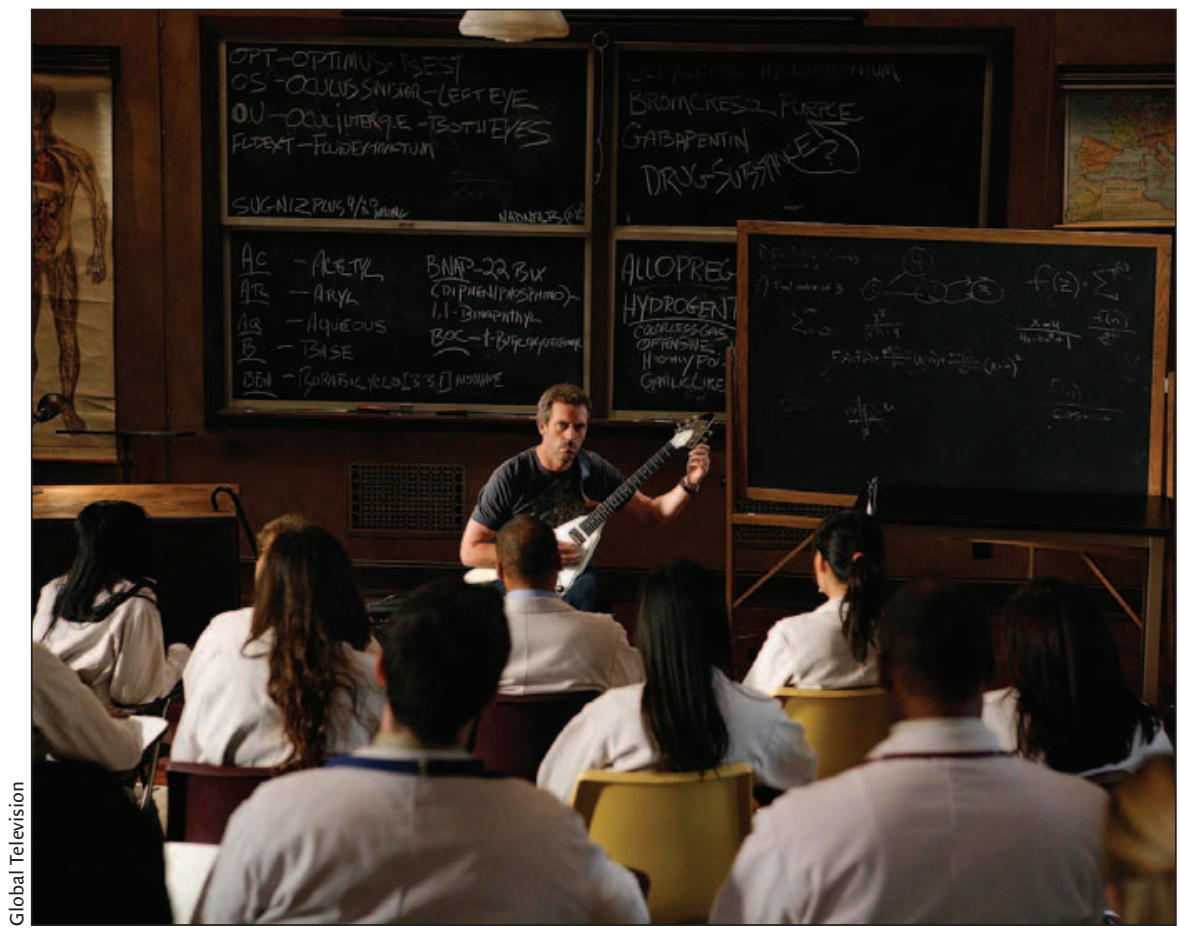

Greg House's single most attractive characteristic is that while eager to be right he is usually wrong, at least until the final minutes of an episode.

knowledge and logic, but an acuity that perceives symptoms others ignore. This is the doctor as detective and the disease as a criminal, ultimately unmasked and humbled.

Implicitly, the show insists on medical knowledge as partial and uncertain, the ability to categorize problematic conditions correctly as a struggle worthy of rigorous effort. Richard Chamberlain's Doctor Kildare, which ran from I96i to Ig66, would not have lasted an episode on House's team. Dr. Kildare never worried about being wrong. He knew the answer, and like House's fellows, typically blamed a pa- tient's lifestyle and life choices.

House, on the other hand, does not judge. But then, Gregory House is neither a paragon nor an exemplar. Nor does he care about the patient. His sole focus is the unnamed disease that attacks the man, woman, adolescent or child whose condition catches his attention. The goal is not to address the patient but to find out what is wrong and hopefully fix it. And even if he can't, at least the patient will know the nature of his or her demise. House is aghast, in one episode, when a patient says she does not care what the disease attacking her might be; that she is 
about to die is knowledge enough. Not knowing, not caring to know, are deaths to House, his secret fear.

Marcus Welby, $M D$, the kindly family practitioner who treated prime-time patients from September 1969 through a final episode in July 1976 , rarely faced medical uncertainty. His medicine promised care and kindness within a science that always knew the problem and how to fix it. So, too, did the doctors of St. Elsewhere (1982-I988) and Chicago Hope (1994-2000) for whom medicine's real challenges, as it is on Michael Crichton's ER, were economic and hospital bureaucracies within which the fictional doctors practised.

House is the diagnostician for today, a time when emerging infectious diseases are again ascendant and it has become clear to all that our knowledge is often inadequate to easily identifying their nature or reversing their effects. Medicine is again a partial science and House M.D. presents it at the frontier where diagnosis is a rigorous art, a balance between ignorance and knowledge.

Working under House in his first 3 seasons were attending physicians in neurology (Dr. Eric Foreman), intensive care medicine (Dr. Robert Chase) and immunology (Dr. Allison Cameron). They tolerated his sarcastic bullying because, all said, he would make them better doctors. He did this by insisting they think beyond their sense of the patient-as-person, and beyond the standardized tests and easy answers, to the nature of the disease itself.

This is another reason for the show's success: Gregory House knows he can't do it alone. Holmes needed his Watson; House needs his underlings and their easy answers if he is to find the hard truths. When they are unavailable he'll take anyone available - in the first issue of the fourth season it is a janitor - as a backboard for his thinking. Those who think House's method is Socratic, misunderstand his method. He does not teach what he knows but uses others to push past the easy and convenient answers to the real truths that lie beyond. House is the doctor of uncertainty, his diagnostics an old medicine rethought and repackaged for a new age of advancing disease.
Tom Koch PhD

Adjunct Professor of Medical

Geography

Vancouver, BC

\section{REFERENCE}

I. Neely K. Atrium: The Report of the Northwestern Medical Humanities and Bioethics Program. Issue 3. Is there a doctor in Greg House? Chicago: The Program; 2006. p. I9-20. Available: http://bioethics .northwestern.edu/atrium/atriumissue 3.pdf (accessed 2007 Oct 23).

\section{FURTHER READING}

I. Holtz A. The medical science of House. New York: Penguin (Berkeley Publishing Group); 2006.

2. Challen P. The House that Hugh Laurie built Toronto: ECW Press; 2007.

Tom Koch (http://kochworks.com) is a consultant in gerontology and medical ethics at the Copeman Healthcare Centre in Vancouver, BC, and author of 14 books, most recently Cartographies of Disease (2005).

\section{Poem}

\section{The Script}

I watch you watch me,

As I open the door slowly,

Carefully,

As if drawing open the curtain

On the first act

Of this new chapter of your life.

Your eyes drift from my face

To the bright red file I hold

Clutched tightly in my hand.

Almost bursting at the seams,

The script, as it were...

A running commentary on your life.

It is a script you help write

But never actually read.

All you see is the cardboard cover...

The contents are for my eyes only.

Yet I read the words out to you

At each and every visit.

But today is different

Something unexpected in the plot...

A twist, a turn,

Which occurred silently

Deep within you.

You provided the material

But it was an inspiration no one

wanted...

Sometimes the script

Takes on a life of its own.

I, myself, do not want to play this part... This is a monologue I don't want to read
But it is part of the performance.

After all, there have been happy

monologues

Soliloquies of joy

Wherein you sat and beamed

Proud of your accomplishments

And the script was punctuated

By the footnotes of your life:

Babies, milestones, triumph over pain, Personal goals realized.

I close the door behind me

The office clock beats loudly in the

silence

Like a drum roll preceding my

opening words

Should I set the stage

Or jump to the climax?

You shift uncomfortably in your chair

This is not the performance you

bargained for...

But the script is by no means finalized There is always room for revisions Your epilogue is yet to be written. We shall complete it together And hope for better inspirations And more positive turns of plot. As we navigate the story of your life.

\section{Pari Basharat}

Medical student

London, Ont. 